This article was downloaded by: [University College London]

On: 28 J une 2015, At: 05:59

Publisher: Routledge

Informa Ltd Registered in England and Wales Registered Number: 1072954 Registered office: Mortimer House, 37-41 Mortimer Street, London W1T 3J H, UK

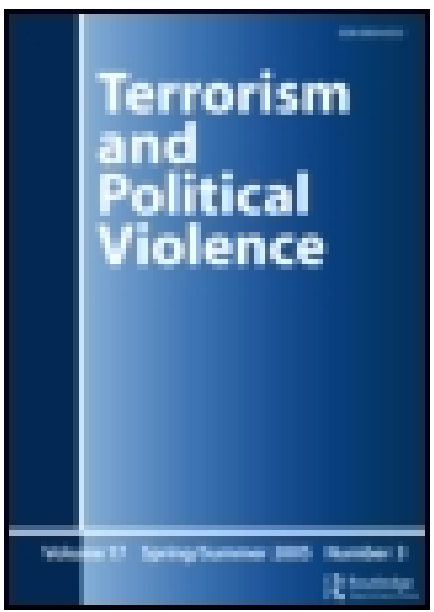

Terrorism and Political Violence

Publication details, including instructions for authors and subscription information:

http:/ / www. tandfonline.com/ loi/ ftpv20

\title{
Research Note: Hassan al-Turabi, Osama bin Laden, and Al Qaeda in Sudan
}

\author{
Max Taylor ${ }^{a} \&$ Mohamed E. Elbushra ${ }^{b}$ \\ ${ }^{a}$ Department of Applied Psychology, University College Cork , \\ Ireland \\ ${ }^{b}$ Director for African Centre for Criminal J ustice Research, \\ Khartoum, Sudan \\ Published online: 25 J an 2007.
}

To cite this article: Max Taylor \& Mohamed E. Elbushra (2006) Research Note: Hassan al-Turabi, Osama bin Laden, and Al Qaeda in Sudan, Terrorism and Political Violence, 18:3, 449-464, DOI: 10.1080/09546550600752022

To link to this article: http:// dx.doi.org/ 10.1080/09546550600752022

\section{PLEASE SCROLL DOWN FOR ARTICLE}

Taylor \& Francis makes every effort to ensure the accuracy of all the information (the "Content") contained in the publications on our platform. However, Taylor \& Francis, our agents, and our licensors make no representations or warranties whatsoever as to the accuracy, completeness, or suitability for any purpose of the Content. Any opinions and views expressed in this publication are the opinions and views of the authors, and are not the views of or endorsed by Taylor \& Francis. The accuracy of the Content should not be relied upon and should be independently verified with primary sources of information. Taylor and Francis shall not be liable for any losses, actions, claims, proceedings, demands, costs, expenses, damages, and other liabilities whatsoever or howsoever caused arising directly or indirectly in connection with, in relation to or arising out of the use of the Content.

This article may be used for research, teaching, and private study purposes. Any substantial or systematic reproduction, redistribution, reselling, loan, sub-licensing, systematic supply, or distribution in any form to anyone is expressly forbidden. Terms \& Conditions of access and use can be found at http://www.tandfonline.com/page/termsand-conditions 


\title{
Research Note: Hassan al-Turabi, Osama bin Laden, and Al Qaeda in Sudan
}

\author{
MAX TAYLOR \\ Department of Applied Psychology, University College Cork, Ireland \\ MOHAMED E. ELBUSHRA \\ Director for African Centre for Criminal Justice Research, \\ Khartoum, Sudan
}

\begin{abstract}
This research note explores the events and circumstances surrounding Osama bin Laden's stay in Sudan from 1991 to 1996. In particular, it discusses the role that the Sudanese politician, Hassan al-Turabi may have played in the development of bin Laden and al Qaeda. It draws particular attention to the role of the Popular Arab and Islamic Congress (PAIC) in the emergence of a distinctive form of Radical Islam and offers a preliminary discussion of the emergence of particular qualities of al Qaeda ideology.
\end{abstract}

Keywords al-Turabi, Osama bin Laden, Sudan, al Qaeda, PAIC

Speculation about the nature and role of Al Qaeda and Osama bin Laden preoccupies much of the contemporary popular and professional literature of terrorism. Al Qaeda and bin Laden may not of course be synonymous (in that influences on one may not necessarily directly influence the other). But even given this, and despite such an enormous outpouring of material on both, from at least an academic perspective there is relatively little on which to base analysis of the ideological influences $^{1}$ on bin Laden or Al Qaeda. Bin Laden himself does not offer much by way of evidence of systematic thinking (at least expressed in any accessible written way), and whilst the ideological expression of Al Qaeda might benefit from and draw on more general radical Islamic thinking, there is little on which to base specific analysis of its idealogical prospectus. Given this relative vacuum, it is important to try to identify and understand circumstances that might have influenced the

Max Taylor is Professor in International Relations at the CSTPV, University of St. Andrews. $\mathrm{He}$ is a forensic psychologist with particular interests in ideology and behavioural approaches to understanding terrorism. Mohamed Elamin Elbushra holds a PhD in Criminal law and Criminal Justice from Keio University Japan. He is a former Major General of Police and Director of the CID, Sudanese Police. He was a Professor of Criminal Law at the Naif University, Riyadh, Saudi Arabia, and is Senior Consultant in Criminal Justice and Crime Prevention at the Ministry of the Interior, UAE.

Address correspondence to Max Taylor, CSTPV, University of St. Andrews, Fife KY16 9AJ. E-mail: gm39@st-andrews.ac.uk. This paper arises from research undertaken whilst the author held an Irish Council for the Humanities and Social Sciences Senior Research Fellowship. 
development of Al Qaeda and/or bin Laden. Necessarily such analysis will be speculative, and in the absence of firm evidence, tentative.

This research note focuses on Osama bin Laden and the possible effects on him, or on Al Qaeda more generally, of experiences in Sudan. Bin Laden's commercial and family background are relatively well-known, as are some details of his involvement in Saudi Arabia and rejection of U.S. involvement in the Kingdom, his experiences of violent resistance in Afghanistan, and his growing association with radical dissident Islamic elements in these countries. What is much less clear is in developmental terms what the specific influences are that he was exposed to, and how his current behaviour relates to that exposure. In particular, we lack information about the factors that led to the emergence of Al Qaeda as a global, as opposed to a regional, force. To explore this fully would be an enormous undertaking, probably beyond the limits of current knowledge, and certainly beyond the limits of this research note. On the other hand, there are some tentative avenues that can be identified that might indicate some of the influences on bin Laden (or more generally Al Qaeda) that perhaps give clues to perspectives on how his views on Islam might be propagated and how that might be expressed in behaviour and activities.

As noted above, this research note is speculative and tentative. It primarily addresses the period when bin Laden lived in Sudan from 1991 to 1996 and specifically raises questions about experiences during that time that may have influenced his subsequent activity. Prefaced by a brief contextual introduction, an annotated time line is presented, which outlines bin Laden's involvement in Sudanese life, and his engagement with radical Islamic thinking in Sudan. The thrust of this research note is specifically to open debate about the potential influence on bin Laden of the thinking and activities of Hassan al-Turabi, and more generally (but in a limited way) to open an exploration of the influence of al-Turabi on both $\mathrm{Al}$ Qaeda and the expression of contemporary radical Islamic thinking. Although of course it is necessary to ground al-Turabi's activities within the complex political environment of Sudan, al-Turabi did have a distinctive, internationally focussed, and essentially decentralized, perspective on propagating radical Islam in which bin Laden was in some measure involved whilst he was in Sudan. In the brief discussion following the time line, this is further developed.

\section{Context}

On June 30, 1989, a military coup in Sudan, lead by Lt. General Omar Hasan Ahmad al-Bashir, overthrew the democratic parliamentary civilian regime of Sadiq al-Mahdi. A central feature of Sudanese political life from independence in 1956 up to that time was dispute about the role that Islam might and should play in the life of Sudan, and in particular over the way in which that might be expressed through the introduction of Shari'a. To a large extent it was al-Mahdi's failure to succesfully resolve the issues associated with this and the issue of the peace process in Southern Sudan that lead to the military coup of 1989. The issue of Islamisisation was (and remains) a source of enormous political tensions within Sudan, not simply in the Islamic north but also the Christian south where it is still most clearly associated with the unfavourable conditions generated by the five decades of civil war.

A central figure in the development of Islamisisation in Sudan throughout much of the period since independence has been al-Mahdi's brother-in-law, Hassan Abdullah al-Turabi. Al-Turabi was a fomer Dean of the School of Law at the 
University of Khartoum, and was secretary general of the Sudanese Muslim Brotherhood (Ikhwan) since 1964. Although in origin the Sudanese Ikhwan was associated with the Egyptian movement, it was also greatly influence by Pakistani Jamaat Islami which led to strong ties with the late Gen. Dhiyaa Al-Haq, President of Pakistan. A further unique quality of the Sudanese movement was the significance of the mystical Mahdist movement, a critical factor in the revolutionary struggles in pre-independence Sudan, and parallel with this a less than enthusiastic acceptance of communism. ${ }^{2}$ Al-Turabi's overall contribution seems to be best characterized as a pragmatic ideologue and theologian, who principally emphasized the importance of quasi-democratic structures in the propagation of radical Islam, in contrast to the Egyptian model of military dictatorship or other more autocratic regimes, operating within the framework of a radical and modernizing Islamisisation process. A distinctive feature of al-Turabi's approach relates to the role of the State, which from his perspective was seen as a secondary vehicle for the attainment of an Islamic society, its task being to create the conditions for reform, rather than the imposition of reform through the State. The rise of al-Turabi's political influence in Sudan, and that of the Muslim Brotherhood, can be seen as follows:

1. During 1964, al-Turabi emerged as the most distinguished political and religious leader in Sudan. His role and speeches in the Round Table Conference held to solve the Southern problem revealed him as one of the leaders of the Sudanese people's uprising known as 24th October revolution 1964, which was against the first military government in Sudan. Indeed, in Sudanese terms, al-Turabi emerged as the major intellectual to lead the Islamic movement, and he gave the Ikhwan a new image and attraction among university and secondary school students, the generation which is now holding power in Sudan.

2. Following the overthrow of the military government of Gen. Ibrahim Abood, al-Turabi won with a significant majority one of the electoral seats allotted to intellectuals in the Parliament. In 1965, with only two members of his Islamic Charter Front Party, al-Turabi subsequently won a major struggle against the Sudanese Communist party, by leading the parliament to pass a resolution disbanding the Communist party and unseating its fourteen members of the parliament; this played a significant part in empowering political Islam in Sudan.

3. During the Numeiri regime of the 1970s, and later in 1983 as Numeiri's Attorney General, al-Turabi played a controversial role in the introduction of Shari'a in Sudan. However, perhaps his most significant achievement in this period was building up the economic power of his own political party (although it was banned at that time). In 1985, following the overthrow of Numeiri, al-Turabi in opposition established the National Islamic Front (NIF) that continued to actively advocate the implementation of Shari'a as the central element in the creation of an Islamic society.

After the Islamist military coup in 1989, al-Turabi (along with the leaders of other political parties) was arrested and reportedly held in solitary confinement for several months. However, during that time there was a widespread view that al-Turabi, despite being in prison, exercised considerable influence on the Islamisisation policy of the military government through his supporters in government. A number of National Islamic Front members were in the cabinet, and the overall Islamic direction followed that advocated by al-Turabi. On his release, al-Turabi 
and the National Islamic Front became much more central to Sudanese political life. In 1996 he was elected to parliament and selected as Speaker, the constitutional successor in the event of the President's death, a post he held until 1999 when he appears to have fallen from grace. However, al-Turabi's significance is not simply as a Sudanese politician; his influence extends beyond Sudan and he has played a significant part in the development of radical Islam more generally, ${ }^{3}$ in many parts of the Islamic world, including Iran, Algeria, Pakistan, and Palestine.

Al-Turabi was born in 1932 in Kassala, Eastern Sudan, the son of a religious judge (qadi). He completed a B.A. in Law at the University of Khartoum in 1955, and then studied in the University of London where he gained an M.A. in 1957. His political activism was evident during this time, and in 1954 he was part of the original foundation of the Sudanese Muslim Brotherhood as noted above. Whilst he was a student in London, he was also Secretary General of the Sudanese Students Union in the United Kingdom, and later Secretary General of the Islamic Society for the Support of the Algerian Cause. ${ }^{4}$ After begining an academic carreer in Sudan, he went to The Sorbonne in France where he graduated in 1965 with a Doctorate in Law. ${ }^{5}$ On his return to Khartoum, he became Dean of Law at the University of Khartoum (at an unusually early age), but in 1965 retired from that position to develop further a career in politics. It seems to be from this period onwards that al-Turabi established his future power base amongst young people attracted by his political Islamic agenda.

Although personally close to Jaafar Numeiri, as his classmate in Hantoub Secondary School, in 1969 after the military coup that put Numeiri in power, al-Turabi was arrested and spent nearly seven years in prison. However, in what apeared to be a reconciliation in 1977, he was released and was appointed a member of the leadership council of the Sudanese Socialist Union, the only legal political party of that time. In 1979 he was appointed Justice Minister, but was removed in 1983 and demoted to Presidential Foreign Affairs Advisor. ${ }^{6}$ Reportedly because of American pressure on Numeiri to sever his relations with Islamisists, in 1985 al-Turabi was again imprisoned, being released on Numeiri's downfall later the same year. After a period in opposition after the general election of 1986, in 1988 he joined a coalition goverment headed by al-Mahdi and was appointed Minister of Justice, then Minister of Foreign Affairs and Deputy Prime Minister.

Al-Turabi's international political significance in terms of broader radical Islamic activity dates back to 1977; however, he began to work openly in the international arena following the military coup of 1989 , when he used his increasingly powerful position to exercise influence not just in Sudan, but in the broader Islamic world. He is undoubtedly a man of considerable intellectual stature, and has written some ten substantive works of Islamic scholarship and a number of other pamphlets and occasional papers, ${ }^{7}$ but his pragmatic activism and facilitation of co-operation and liaison between disparate radical Islamic groups are the chief marks of his international significance, along with his distinctive theological perspective on the development of radical Islamic thinking. In Sudanese political terms, he seems to have been a pragmatic politician driven by a clear ideology related to the development of radical Islam within Sudan as a model for the world at large.

Although al-Turabi is a significant figure in the contemporary Islamic movement, opinon is divided on the theological merits of his scholarly works when compared with the other Muslim intellectuals of his era. It can be argued that his writings did not outline any clear understanding of Islamic revival, because his concept of 
Islam was essentially political in character. His recent writings seem to confirm this. ${ }^{8}$ On the other hand, al-Turabi is clearly a figure of consequence in the radical Islamic world (a role that merits further exploration). However, his significance for this research note lies not so much in the adequacy or otherwise of his intellectual contribution, but in the presence in Sudan from the period 1991-1996 of Osama bin Laden, and the influence al-Turabi might have had on the emergence of the internationalist agenda of Al Qaeda. The following annotated time line explores this further, as does the brief following discussion.

\section{Annotated Time Line}

The following summarises the context to and major landmarks in relation to Hassan al-Turabi, and bin Laden's period in Sudan.

1950s Onwards. Foundation of a series of Islamisist organisations in Sudan under the leadership of Hassan al-Turabi. The political parties he founded during this time were variously known as the Sudanese Muslim Brotherhood or the Ikhwan (1955), the Islamic Charter Front (1964), the Islamic Trend (1985), the National Congress in 1991, and the Popular Congress in 2000. The Popular Arab and Islamic Conference (PAIC) (1991) was one of his critical innovations in the context of globalization of radical Islam. The PAIC was an attempt by al-Turabi to hand over the internal affairs to his students in Sudan and look for global Islamist leadership with the intention of enhancing his theory of Islamic revival. This was suggested by his deputy, Ibrahim Al-Sanosi, who stated in 1991: "Now we have accomplished our role in the internal affaires of Sudan, and we have to move with our duties beyond that." All of these organisations founded in Sudan followed the same broad Islamist agenda developed by al-Turabi, merely changing names as necessary: "The movement of Islam in the Sudan, and I do not give it any particular title because it has been changing and developing all the time, is a movement of perpetual change and renewal." 9 Al-Turabi's activities during this time, and his involvement with many young people and students, created the power base on which al-Turabi could later exercise political influence without necessarily being in power. Sudan.

1969 Military coup established Col, Gafaar Muhammed Numeiri as President of

1983 September decrees promulgating Shari'a law. Al-Turabi was not involved in the original formulation of the Shari'a decrees, and indeed was explicitly excluded from discussions, as were the Ikwhan leadership in general. Numeiri greatly distrusted the Ikwhan, and rapidly moved to limit its and al-Turabi's influence after the promulgation of the Shari'a laws by demoting al-Turabi from Attorney General to the post of legal advisor, and then to the position of foreign affairs advisor. The imposition of Shari'a was opposed by Sadiq al-Madhi on the grounds that the conditions for the creation of a truly Islamic state had not been met. U.S. and Egyptian pressure on Numeiri led to the arrest of al-Turabi and other Ikwhan leaders in March 1985, but on Numeiri's downfall in April of that year, one of the first acts of the military leaders who successfully staged the coup against Numeiri was to send a plane to El-Obeid to bring al-Turabi and other Ikwhan leaders from prison to Khartoum, giving them the honour of the heroes who fought against the Numeiri regime. In fact, the military leaders who staged the coup were largely Ikhwan members or sympathizers. 
1984 Al-Turabi and bin Laden met in Khartoum, later London and Afghanistan. ${ }^{10}$ Burr and Collins (2003) suggest bin Laden visited al-Turabi in Sudan in 1984 with subsequent meetings in London and Afghanistan, but that it was not until the military coup of 1989 that bin Laden seriously considered establishing a presence in Sudan. ${ }^{11}$

1985 Overthrow of Numeiri regime by military coup.

1986 Election of Sadiq el-Mahdi as Prime Minister of Sudan. Al-Turabi and his NIF party recorded a new peak in the number of seats in the parliament by winning fifty seats. This was a significant forward step for radical Islam that seems to have encouraged Islamists in Algeria to follow the democratic path.

1988 Bin Laden established Air Charter Company in Khartoum. ${ }^{12}$

1989 Military coup in Sudan bringing to power the current President, Lt. Gen. Omar Hasan Ahmad al-Bashir. ${ }^{13}$

1989 Formal explorations to move members of Al Qaeda to Khartoum.

1989 Bin laden established initial holding company in Khartoum (wadi al-aqiq). Wadi al-aqiq used as its bank the Al Shamal Islamic Bank in Khartoum that had ties with al-Turabi and the Ikhwan through one of the bank's founders, Mutasim Abd Al-Rahim. ${ }^{14}$ In 1990 bin Laden reportedly began to buy property in Sudan. ${ }^{15}$

1990 Bin Laden's family construction company (The bin Laden International Overseas Company) gained contracts to build a new airport at Port Sudan. Osama bin Laden does not appear to have been directly involved in the construction of the airport, but he was subsequently awarded contracts to operate and maintain it. ${ }^{16}$

1990 Foundation by al-Turabi of the Popular Arab and Islamic Conference (PAIC), radically extending the Saudi-dominated Organization of the Islamic Conference $(\mathrm{OIC})^{17}$ and against Iran's Khomeinism. ${ }^{18}$

1991 Bin Laden left Afghanistan for Sudan. Bin Laden's departure was reputedly finally precipitated as a result of Saudi acceptance of U.S. troops, although his relations with the Saudi authorities had become seriously strained before this date. On his arrival, a lavish reception was held in his honour by al-Turabi in Khartoum. At this time, bin Laden is reported as having made a $\$ 5$ million donation to al-Turabi and NIF.

1991 Bin Laden married a member of al-Turabi's family, and established a close personal friendship with al-Turabi. Bin Laden is reported to have four or five wives and al-Turabi's relative was his third wife. In 1996 bin Laden reportedly took as his fourth wife the daughter of a Taliban leader. Both these marriages are consistent with reports that bin Laden used marriage to cement and develop political relationships. At this time bin Laden was allowed to import materials into Sudan duty-free. ${ }^{19}$

1992 Sudanese passports widely issued to Al Qaeda associates.

1992 Al-Turabi seriously assaulted at Ottawa airport. ${ }^{20}$

1992 Bin Laden given land rights to one million acres in Gash River Delta. According to Peter Bergen, "In the Sudan alone, bin Laden owned the most profitable businesses in Sudan, including 'construction, manufacturing, currency trading, import-export, and agricultural enterprises.' These businesses were run on a commercial basis, and at least some profits were used to support 'local Al Qaeda cells that in essence became entirely self-sufficient, self-reliant terrorist entities in the countries within which they operated.",22 Yael Shahar ${ }^{23}$ notes that el-Hijrah for Construction and Development Ltd, a construction company owned by bin Laden in partnership with the National Islamic Front (NIF) and the Sudanese military, built the $1200 \mathrm{~km}$-long highway linking Khartoum to Port Sudan. The Sudanese Government paid for part of this construction work by giving bin Laden ownership 
of the Khartoum Tannery. ${ }^{24}$ Other companies noted as being owned by bin Laden in Sudan include the "Wadi al-Aqiq" Company (referred to above) and the Taba Investment Company Ltd. ${ }^{25} \mathrm{He}$ was also reportedly "part-owner of the "el-Shamal Islamic Bank' in Khartoum, a joint effort with the NIF, in which bin Laden is said to have invested $\$ 50$ million" (see above). Various witnesses in the U.S. Embassy bombing trials ${ }^{26}$ refer to Al-Qaeda running farms in Sudan, which produced a variety of crops, from peanuts to sunflowers. However, the land was also reportedly used for weapons and explosives training. Yael Shahar ${ }^{27}$ notes that "other enterprises in Sudan included the Laden International import/export company; a bakery; a furniture company; the Bank of Zoological Resource cattle-breeding operation; and the International al-Ikhlar Co., which made honey and other sweets." There is evidence of export of these various items through Cyprus, evading international sanctions against Sudan. Shaul Shay also lists a range of companies owned by bin Laden. ${ }^{28}$ Bin Laden does not appear to have been personally politically active whilst he was in Sudan, either in terms of domestic politics or in terms of international initiatives. He was held under close surveillance and control during his period in Sudan, which may in part account for this, but it also seems that his role was to develop business interests, and through these finance other people's activities. This is illustrated by bin Laden's financial and personnel support to Islamists in Somalia from Sudan. It is tempting to draw parallels between bin Laden's role as a background financial influence and al-Turabi's role as a background figure of political influence.

1993 Intercept of call from Sudanese Rep. at UN to al-Turabi makes reference to bin Laden's supportive role in attack on 1993 World Trade Center. J. Millard Burr and Roberto Collins ${ }^{29}$ argue that Sudan was intimately involved in the bombing attack against the New York World Trade Center in 1993, in terms of planning, logistics, and personnel. After the bombing, in July 1993, two Sudanese diplomats were arrested on suspicion of being involved in the bombing, and were subsequently deported. They also suggest that the FBI intercepted a telephone call from the Sudanese Representative at the UN to al-Turabi, which allegedly involved reference to bin Laden.

1993-95 Bin Laden allegedly provided funding for mujahedeen in Bosnia through humanitarian agencies operating primarily in Zenica.

1993 Bin Laden appointed member PAIC General Assembly —al-Turabi General Secretary.

1994 Contacts between al-Turabi and the French authorities concerning Ilich Ramirez Sanchez (Carlos the Jackal) The Sudanese authorities negotiate the sale of Sanchez to the French Government. ${ }^{30}$

1994-5 Through their offices in Sudan, Hizbollah, Hamas, Islamic Jihad, and Al Qaeda collaborate through PIAC General Assembly.

1994-95 Iraqi weapons moved to Sudan. There have been repeated but unconfirmed reports that Sudan may be in possession of Scud missiles exported from Iraq to avoid their destruction by UNSCOM. A February 1998 U.S. congressional task force report, produced by Yossef Bodansky, alleged that in mid-1991, "about 400" Scud missiles were transferred from Iraq to Sudan, and that in late 1995, "some 50 'advanced Scud launchers' and a similar number of Al Hussein missiles" were shipped from Iraq to Sudan. ${ }^{31}$

1995 Bin Laden reportedly sponsored attack on Saudi Arabia organised from Sudan + attack in Pakistan.

1995 Attack on Hosni Mubarack, President of Egypt on June 25 in Addis Ababa. ${ }^{32}$ 
1996 President Bashir offers extradition of bin Laden to Saudi authorities for passing on to U.S. (negotiations between Sudanese Government and CIA) to improve relations with Saudi Arabia. ${ }^{33}$

1996 Bin Laden returns to Afghanistan May 18. Broader efforts in 1996 to improve Sudanese relations with neighbours.

1996 Al-Turabi issued support for bin Laden after attack on Khobar Towers in Dhahran. $^{34}$

1997 Bin Laden briefly in Khartoum and met al-Turabi.

1998 Bin Laden sent Sudanese Colonel Ahmad al-Gamen to Mindanao to train MILF members in explosives and commando techniques. D. M. Jones et al. cite as a source for this the Republic of Philippines Directorate for Intelligence, "Reference Folder on International Terrorism," National Headquarters, Philippine National Police, Camp Crame, Quezon City (1999), p. 2. The document is marked D1, and classified as secret. ${ }^{35}$ This suggests a continuing relationship with the Sudanese authorities after bin Laden had left Sudan.

1998 U.S. attack Al-Shifa pharmaceutical factory in Khartoum North, August 20. There was no known Al Qaeda or bin Laden involvement with the plant, although this was used as part of the justification for the U.S. attack; the principal justification being that it was being used for the production of chemical weapons. ${ }^{36}$

1998 Dissolution of Sudanese Parliament, and national emergency declared. AlTurabi's influence apparently greatly diminished, and he was arrested in 2001. In 2004, al-Turabi was re-arrested over an alleged coup plot against the al-Bashir government.

\section{Comments}

The above describes a series of events, and implies associated relationships, but in the absence of open disclosure by the principals involved, it is impossible in some cases to confirm details let alone evaluate influence. Nevertheless, that there was an emergent relationship between al-Turabi and the PAIC and bin Laden and other elements of Al Qaeda is undoubtedly the case, and given al-Turabi's ideological sophistication, is cause for at the least speculation about influence, if not confirmation.

Max Taylor and John Horgan ${ }^{37}$ have emphasised the role that ideology plays in the development of the direction of behaviour in terrorism, drawing particular attention to the concept of "community of practice",38 as an explanatory vehicle for transmission of ideology. Clearly the sources of ideological effects on anyone are complex, but suggestive indications may be apparent in bin Laden's or more general Al Qaeda experience in Sudan and association with al-Turabi. As an example of speculating about such influences, one interesting avenue that might be further explored relates to the influence on bin Laden of al-Turabi's concept of the process of emergence of future Islamic states. Before his arrival in Sudan, bin Laden had already had experience of the role of radical violent Islam in Afghanistan, and in particular had seen how effective violent insurgency might be in opposing Western influence. But unlike Ayman al-Zawahiri, the reputed deputy leader of Al Qaeda, bin Laden has little or no formal training in Islamic theology, ${ }^{39}$ and as far as can be judged lacks the critical apparatous to put his experiences into a sophisticated broader Islamic perspective. ${ }^{40}$ Up to his arrival in Sudan, bin Laden's interests seem to have been largely focussed on the state of Islam in Saudi Arabia and its development in Afghanistan, and there is little evidence of any interest in broader issues outside of Russian involvement in Afghanistan, let alone any notion of global jihad. Although al-Zawahiri had liaised 
with bin Laden in Afghanistan, it was not until 1998 that their respective organisations were thought to have merged, and it is possible, therefore, that al-Turabi may have exercised influence towards a global and outward looking agenda for Al Qaeda at a critical period in bin Laden's political development. However, al-Zawahiri did have contact with al-Turabi during the Second PAIC in April 1995, during which plans were drawn up to address U.S. involvement in Somalia (see end note 18). In this coming together, it is intriguing to speculate if this point marks the beginning of the process that led to the U.S. rather than Saudi Arabia becoming the focus for Al Qaeda and bin Laden.

Al-Turabi might be described using the term he used of his ancestor Wad alTurabi as a "reformist-jihadist." ${ }^{41}$ He sees the process of Islamisisation as essentially an evolutionary process, emerging out of consensus "based on shura or consultation and ijmaa or consensus." In this al-Turabi reflects the influence of al-Afganhi, Qutb and Maududi, although al-Turabi is quite clear that leadership of the emergent consensus lies with suitably qualified people, and is not in this sense democratic in a Western sense. ${ }^{42}$ As noted earlier, in his view the role of the State in this emergence is not necessarily to lead, but rather to facilitate the emergence of social Islam, which in turn will lead to the emergence of the truly Islamic State, the dar al-islam.

Al-Turabi describes how he sees the scope of government as follows ${ }^{43}$ : "The scope of government is limited. Law is not the only agency of social control. Moral norms, individual conscience, all these are very important, and they are autonomous." He notes that "the presumption is that people are free. The religious freedom not just of non-Muslims, but even of Muslims who have different views, is going to be guaranteed.... There has never been any question of inhibiting people's freedom to express any understanding of Islam. The function of government is not total." 44 The emphasis on the role of the individual and of moral values is of significance (although it should also be noted that it is the "informed" individual whom this refers to). "Islamic government is not total because it is Islam that is a total way of life, and if you reduce it to government, then government would be omnipotent, and that is not Islamic."45

In his conversations with Mohamed Hamdi, ${ }^{46}$ al-Turabi expresses these ideas further, suggesting four stages through which Islamisisation will take place. The first stage is when the Islamic revival is a trend reflecting "spontaneous awareness of the Islamic identity and a need to express and promote it." This emerges as a precursor to the next stage, when this trend becomes evident in organised groups that create through their activities "an embryonic model" of the future Islamic society. The third stage emerges when local groups develop into broader reform movements. These develop action programmes, increase social awareness, and increasingly become political presences. The final stage can be identified when the Islamic movement takes political control. The emergent Islamic movement should be populist, create social structures facilitating leadership and reform, invigorate religious, intellectual, social and cultural life, address the status and role of women, develop Islamic economic systems to "free [Islam] from the rootless influence of capitalism and socialism," engage in political action and develop international relations based on Islamic principles. Central to al-Turabi's theology is a reformist concept of the reapplication of ijtihad (the process of finding God's Law from the Qur'an and the Hadith), drawing on and interpreting contemporary social and scientific views using traditional Islamic theological discourse to create a re-invigorated Islam. Equally central is the way in which moral regeneration and associated jihad creates the 
conditions for reform that will essentially be outside of the concept of the State. Such views may well have great appeal to those individuals living in States that have largely left them behind, or ignored or disadvantaged them.

In many ways the nature of the emergent Islamic State envisaged by al-Turabi can be seen clearly in his account of the role of women in Islamic society, ${ }^{47}$ which describes women's position in terms that at times may not necessarily seem positive to the liberal Western reader but is nevertheless challenging for conservative Islamisists. For example, traditional values are asserted and the wearing of Islamic dress and modesty are emphasised; but in contrast so are women's rights to equality of treatment under the law and rights of control over their own destinies. Although Al-Turabi's ideas are clearly grounded within what might be refered to as a radical Islamic context they cannot be neatly categorised as conservative fundamentalist. Al-Turabi's views on women reflect a more general attempt to place Islam within a modern context that does not deny Western science or social advances and experience, but seeks to embrace them within an Islamic context through ijtihad, and to give them Islamic meaning. As reported by Joyce M. Davis, ${ }^{48}$ al-Turabi describes his thinking as follows: "I'm trying to propose an original model which would have taken advantage of the Western model, which would have taken advantage of the other human values from the West, or from Islam or from christianity or from wherever." This is in striking contrast with Wahabi'ist concepts of Islam, for example, that bin Laden would have been exposed to as a young man in Saudi Arabia (and also al- Zawahira in Egypt). However, it should be noted that the reality of Sudanese life during the period when al-Turabi exercised power and influence in Sudan was far removed from the idealised image of potential social structure described by alTurabi. But the failure to achieve these aspirations in Sudan should not diminish any evaluation of the significance of al-Turabi's ideas within the context of the popular appeal of radical Islam.

To the extent that it is possible to discern any consistent ideological positioning for bin Laden and Al Qaeda, the State as the agent to propagate Islam seems similarly to have a limited role. Al Qaeda's role is to develop the conditions for the emergence of Islam, rather than lead its emergence through the creation of an embryonic State. The state seems to be simply a vehicle and to provide opportunity for a base, rather than a necessary element in the emergence of a broad Islamic movement. Documents such as the Al Qaeda training manual, ${ }^{49}$ for example, suggest the main mission of Al Qaeda to be "the overthrow of the godless regimes and their replacement by an Islamic regime." This does not seem to be developed, at least in that document, as an element in any particular State context (regardless of any ideological position, this of course may also be a recognition of a broad failure to generate representative Islamic states). The manual goes on to stress in a section entitled "Necessary qualifications and characteristics for the organisation's member" 50 the personal and moral qualities of members, echoing al-Turabi's stress on personal moral qualities in the development of the process of Islamisisation. ${ }^{51}$ In terms of al-Turabi's typology described above, the contemporary status of Islamisisation as reflected in Al Qaeda seems to have moved from stage 1 to stage 2. (Presumably the situation in Iran is more advanced in these terms). But Al Qaeda's actions can clearly be seen to be designed to facilitate the emergence of stage 3 , the emergence of broader reform groups, and this is envisaged in the Training Manual. ${ }^{52}$ The informal qualities of the organisation of Al Qaeda also seem to echo the loosely Structured framework al-Turabi created in the PIAC to facilitate the emergence of 
radical Islamic action. Recent comments by al-Zawahira also seem to echo alTurabi's views on "informed and morally appropriate electorates" as elements of Islamic democratic revival. ${ }^{53}$

\section{Coda}

Much more work is necessary to establish whether the tentative links identified in this research note are meaningful and of any significance. Even if these links are accurate, the extent of the influence bin Laden might have exercised on events, as distinct from for example al- Zawahira, is unclear. To complicate matters further, in a more general sense it might be argued that what we see as the expression of contemporary radical Islam (at least in the form exemplified by Al Quada) is not necessarily the expression of any formal ideology related to conventional ideas about the state (and therefore we should not look for its origins in either the work of any particular idealogue or some geographical location), but is in fact a reflection of an emergent ideology based on dispersed communities of practise ${ }^{54}$ held together by a common religious perspective. This reflects at least in part the failure of Islamic communities to organise as effective State or State-like entities (including the development of political and theological responses), but it may also be a reflection of the inherent tension in Islam between the state as a source of power, and the concept of "dar al-islam" and the primacy of religious authority which seems to be an ascendent feature of contemporary Islamic thinking. Indeed, it may be argued that this tension lies at the core of al-Turabi's ideas. This results in "Islam and jihad being used as a substitute for what we would regard as more modern and effective forms of national and political mobilization." 55 This view offers an almost situational bound sense of ideological process and structure grounded in local experience, in contrast to one following explicit, articulated ideological expression - a view much more readily encompassed within contemporary psychological knowledge. It also raises the question of the influence on political expression of situational context, and may even offer some insights into why Al Qaeda's "virtual" structure has emerged. Given this, when placed and interpreted within the framework for analysis proposed by Taylor and Horgan, ${ }^{56}$ this research note may offer additional insights into both the specific influences on bin Laden, and the more general issue of understanding ideological influences on behaviour.

In a sense al-Turabi and bin Laden might be thought to have complemented each other, each providing what the other needed at that time. Al-Turabi was a sophisticated Islamic intellectual, with great political talents; bin Laden had financial acumen and power but lacked political direction and context. At a time when bin Laden needed it, al-Turabi gave shelter and a sense of political direction, and bin Laden in turn provided the Sudanese regime with financial support. However, perhaps of greater local and immediate consequence, bin Laden's support for al-Turabi also significantly aided al-Turabi in factional fighting within the International Islamist movements, and materially contributed to al-Turabi's emergence as a significant leader (in particular over Egyptian influences). Furthermore, there is another sense that can be identifed in which al-Turabi and bin Laden might complement each other, that relates to their sense of the relationship between wealth and power in the development of the Islamic revolution. Both have a pragmatic view on the need to exercise economic and political power to facilitate the process of Islamic revolution. 
Opening Sudan to the radical Islamists from all over the world benefited bin Laden to the extent that it enabled the development and formalization within Sudan of what emerged as future Al Qaeda strategies. In achieving this, it seems that the relationship between al-Turabi and bin Laden was critical. It was al-Turabi who was politically oriented and not violent; in contrast bin Laden was a spiritually motivated fighter, but with unclear political goals. It seems likely that after the end of the Cold War, and the changes in U.S. foreign policy (resulting amongst other things in a loss of support for bin Laden's activites), al-Turabi offered bin Laden a sense of political direction that complemented bin Laden's sense of Islamic jihad. In fact it seems likely that the relationship between bin Laden and al-Turabi predates bin Laden's movement to Sudan, in that there is evidence that Sudanese Islamisists associated with al-Turabi had as early as the 1970s made contact with bin Laden in Saudi Arabia, introducing al-Turabi to him at that time. Given this, it might be argued that the significance of bin Laden's move to Sudan lies not simply in the provision of geographical shelter at a time when bin Laden experienced difficulties, but also in terms of the development of an intellectual and political dimension to future Al Qaeda strategy.

Whatever the nature of the early relationship between bin Laden and al-Turabi, it began to wane over time, and in 1996, differences between them began to emerge and become critical. The gap between their thoughts began to widen, particularly in the issue of women's rights, violence, U.S. relations, and the future of Saudi Arabia, and this along with external presures on Sudan, seems to have resulted as much as anything else in bin Laden's return to Afghanistan.

\section{Notes}

1. In writing this, the authors recognize that the concept of ideological influence may be unclear. Ideology in the sense used here, is broadly consistent with Hall's view that "ideologies are the framework of thinking and calculations about the world - the 'ideas' that people use to figure out how the social world works, what their place is in it and what they ought to do" (Stuart Hall, "Signification, Representation, Ideology: Althusser and the Post-Structuralist Debates," Critical Studies in Mass Communication 2 (1985: 91-114.) The origins of ideology in this context relate to the expression of theological or political ideas. It is interesting to speculate whether the sources of ideology might reflect situational factors, as well as political or theological. See also Taylor and Horgan (2005) for a further discussion of the relationship between ideology and behaviour (Max Taylor and John A. Horgan "Conceptual Framework for Addressing Psychological Process In The Development of The Terrorist," Terrorism and Political Violence, in press).

2. For a discussion of this see Abdelwahab El-Affendi, Turabi's Revolution: Islam and Power in Sudan, (London, Grey Seal, 1991).

3. Ronald A. T. Judy. "Islamiyya and the Construction of the Human Being," in Ahmad S. Moussalli, ed., Islamic Fundamentalism: Myths \& Realities (Reading, UK: Ithaca Press, 1998), 106.

4. These details are given in C-L. L. Sorenson. The Islamic Movement in Sudan: External Relations and Internal Power Struggle after 1989," Unpublished Master's Thesis, Dept. of Political Studies and Public Administration, American University of Beirut, 2002.

5. Al-Turabi's doctoral thesis was written in French with the title "States of Emergency in Constitutional Jurisprudence."

6. See Mohamed Elhachmi Hamdi, The Making of an Islamic Political Leader: Conversations with Hasan al-Turabi, English Translation by Ashur A. Shamis, (Boulder, CO and Oxford: Westview Press, 1998).

7. His best known works are: al-salat 'imad al-din [Prayer, the Principal Pillar of Religion] (1972/77), al-iman wa atharuhu fi hayat al-insan [Faith and its Role in Man's Life] 
(1974), and al-harakat al-islamiyya fi al-Sudan [The Islamic Movement in the Sudan] (1989). His best known pamphlets are collected in Misawi Hamdi, Qadaya attajdid: nahwa manhaj usuli [Issues of Renewal: Towards an Authentic Approach] (1990) See Sorenson (see note 4 above). None of these appear to be currently readily available to non-Arabic speaking audiences. An English translation of "On the position of women in Islam and in Islamic Society" is available online at http://www.islamfortoday.com/turabi01.htm

8. Recently al-Turabi has advocated several critical issues that put him in confrontation with conservative and traditional Muslim scholars, particularly concerning Prophetical reports (Hadith). In a lecture in the Red Sea University, Sudan, in December 2005, Turabi emphasized the right of women in Islam (see note 7 above for details of an earlier account of his views on women). He advocated that women should hold seats in political organizations in Islamic countries, as well as their potential to become Imams. Furthermore, he has rejected Prophetic accounts that refer to the return of Jesus at the end of the world. See also Hassan al-Turabi, Al-Siyasa wa al-Hukum, Politics and Governing, 2nd edition, Beirut, 2004.

9. Cited in Mohamed Elhachmi Hamdi, The Making of an Islamic Political Leader: Conversations with Hasan al-Turabi, (see note 6 above), 62 .

10. Cited without attribution in J. Millard Barr and Robert O. Collins, Revolutionary Sudan: Hasan al-Turabi and the Islamist State, 1989-2000. (Leiden: Koninklijke Brill, 2003), 68.

11. Sageman (Mare Sageman, Understanding Terror Networks Philadelphia: University of Pennsylvania Press, 2004, 39) also refers to bin Laden visiting al-Turabi and implies this took place in 1989 or 1990 . He makes no reference to the earlier contacts referred to by Burr and Collins (see note 10 above).

12. Burr and Collins (see note 10 above).

13. Al-Turabi did not appear to have played a direct role in the military coup that brought down al-Mahdi's government, but he was a central figure in the background. This is a role al-Turabi frequently played.

14. See the U.S. Embassy Bombings Transcript Day 5 Feb. 2001 for details of the use made of the Wadi Aqiqi accounts, http://www.ict.org.il/documents/documentdet.cfm?docid $=46$

15. Trial testimony of Jamal al-Fadl: United States v. Usama bin Laden, No. S(7) 98 Cr. 1023 (S.D. N.Y.), Feb. 6, 2001 (transcript pp. 220-224).

16. There are reports that under the direction of bin Laden the airport was used to move arms shipments. This seems likely to be untrue, because at least at that time there were no planes available to ship such arms. Saddam Hussein did provide arms to the Khatmiya leader Al Mirghany (who was Al Mahdi's partner in the democratic government in 1987) to help that government fight against the southern insurgents.

17. Al-Turabi has always been concerned to maintain the current regime in Saudi Arabia, because he saw it as the backbone of Islamisation and the most favorable environment for breeding Muslim scholars and maintaining Islamic teachings. He was of the opinion that any regime that might replace the Kingdom of Saudi Arabia might be against Islamisation, both regionally and globally.

18. The Popular Arab and Islamic Congress (also known as the General Assembly) was created by al-Turabi as a movement to develop and co-ordinate the Islamic revolution. The first congress was held in Khartoum, April 25-28, 1991. 200 delegates from various Islamic States and movements attended the Congress, including Yasser Arafat. A permanent secretariat was established, with al-Turabi as its Secretary-General. Al-Turabi was already well-known in the Islamic world by this time, and his books and tape recordings of his speeches were widely circulated. This appointment confirmed al-Turabi's stature in the world of radical Islam, and offered him opportunities to extend his influence well beyond Sudan. Significantly, the PAIC included both Sunni and Shia activists (facilitating links to reduce some of the religious and ideological tensions between them), and even included Iranian and Iraqi delegates (Iraqi and Iranian intelligence officers reportedly met during the Congress, a point of some significance given the Iran-Iraq war). Perhaps the greatest outcome of the Congress, however, was the links it enabled to be develop between radical Islamic movements and groups across the world, from the Philippines to Algeria. Al-Turabi played a central role in the facilitation of these links. The second PAIC General Assembly was held in Khartoum in December 1993. During this Assembly, al-Turabi developed links with al-Zawahiri that resulted in a plan to confront U.S. Military activity in Somalia, which may have later influenced planning for more general attacks against the U.S. 
In an interview by Muriel Mirak-Weissbach in Executive Intelligence Review in 1994 (http://www.aboutsudan.com/interviews/hassan_al_turabi.htm) al-Turabi said: "PAIC has assembled Muslims from all over the world, America and Canada and the Caribbean, white and black, Japanese and Europeans, of European stock and European nationalities, Asians, Africans and the Middle East-Arabs mostly. For the first time, from all over the world, we assembled one meeting after the other. We have overcome the internal divisions, Shia, Sunna, differences in jurisprudence or spiritual orders, they now speak together; the dialogue between Christianity and Islam, we were behind it, and trying to develop a dialogue between governments in Muslim countries and societies, whether in Algeria or other countries. And differences between two Muslim countries, Iran and Iraq, what were formerly Southern and Northern Yemen, and the settlement of problems in Afghanistan, some African countries, Muslim minorities all over the world, and dealing with Christian minorities also. This is the first time in world history that Muslim societies have met, not at the diplomatic level, because the Organization of Islamic Conference (OIC) is not representative of the people and is not active."

Another General Assembly meeting was held in April 1995, which further developed the programme of links between radical activist organizations. By 1997, PAIC had offices in Fifty-five Western and Islamic countries including Tehran and Karachi (Sorenson (see not 4 above)). The organization was shut down in February 2000. The PAIC was essentially a decentralized organization, reflecting al-Turabi's views about the conditions that would facilitate the emergence of Islamic revolution. In an interview conducted in 1992, Joyce Davis reports alTurabi's saying "It's an organization rather than a single conference.... All over the world there was a consensus of public opinion and we thought that the official international organizations like the Arab League or the Conference of Islamic States is not truly representative of them all ... and it convenes not only Muslims, but also Arabs, even Christians. Not only Islamic attitudes, but also even nationalist attitudes." (Joyce M. Davis, Between Jihad and Salaam: Profiles in Islam (New York: St Martins Griffin 1999), 12). It may be interesting to speculate if experience of this organizational structure contributed to the eventual development of $\mathrm{Al}$ Qaeda's distributed structure.

19. Burr and Collins (see note 10 above), 70.

20. Al-Turabi was assaulted by a Sudanese expatriate on his arrival at Ottawa airport, resulting in serious injuries. He was admitted into a Canadian Hospital, and subsequently transferred to a clinic in Switzerland. A secret report on the assault was produced for the Canadian Government that has never been released, but there were some suggestions that the assault was committed by an SPLA officer. Al-Turabi (in Davis (see note 18 above), 26) implies that this assault was the result of a conspiracy involving the Canadian Government, because only the Canadian authorities knew of his travel arrangements. Al-Turabi now appears to blame the Sudanese Government for this assault (see Gamal Nkrumah. Hasan Al-Turabi: Remaking History). News article from Al-Ahram posted May 182006 at www.sudan.new/news/posted/12940. This seems to be an example of a more general attempt by al-Turabi to attribute blame for some of the failings of Sudan on the current Sudanese Government and to distance himself from his own role in events.

21. Peter Bergen, Holy Terror, Inc.: Inside the Secret World of Osama bin Laden (New York: Free Press, 2001), 47-49.

22. Ibid.

23. http://www.ict.org.il/articles/articledet.cfm?articleid $=387$.

24. Referred to in U.S. Embassy Bombing Transcript Day 3, Transcript of the trial of suspected al-Qaida militants in connection with the bombings of the American embassies in Kenya and Tanzania on 7 August 1998, http://www.ict.org.il/documents/documentdet.cfm?docid = 44 .

25. Referred to in U.S. Embassy Bombing Transcript Day 7, Transcript of the trial of suspected al-Qaida militants in connection with the bombings of the American embassies in Kenya and Tanzania on 7 August 1998, http://www.ict.org.il/documents/documentdet.cfm?docid $=48$.

26. See U.S. Embassy Bombing Transcripts documents at http://www.ict.org.il/

27. http://www.ict.org.il/articles/articledet.cfm?articleid $=387$

28. Shaul Shay, The Red Sea Terror Triangle: Sudan, Somalia, Yevuea, and Islamie Terror (New Brunswick, NJ, Transaction Publishers, 2005). Shay lists the following as commercial organizations developed or owned by bin Laden in Sudan: Wadi al-Aqiq - an international commerce company; Ladin International Company - an international commerce company; Al-Hijra Construction; Al-Themar Agricultural company; Taba Investments - a commercial 
company that held a monopoly over the export of agricultural products including rubber, corn, and sunflowers; The Blessed Fruit Company; Al-Ikhlas - a candy manufacturer; AlQudurat - a shipping company; A leatherwork company (unnamed); A bakery (unnamed); A furniture factory (unnamed). Shay's source for this list is given as Fever 2001 (A. Fever, "Bin Laden Group had extensive network of companies, witness says," New York Times, 13 February, 2001).

29. Reference to this is made in Burr and Collins (see note 10 above), 121.

30. Ilich Ramirez Sanchez (known as Carlos the Jackal), is thought to have arrived in Sudan during 1993; he entered the Sudan bearing a Jordanian passport with an Arab name Abdalla Barakat. Sudanese officials denied his presence in the country, but he was identified participating in the PIAC General Assembly held in Khartoum 2-4 December 1993 (see note 18 above). Abu Nidal was also living in Sudan at that time. Sanchez appears to have participated in training activities in Sudan, but his relationship with senior Sudanese officials rapidly deteriorated. The French Government had a particular interest in the capture of Sanchez (amongst other things, as a result of his bombing the Saint-Germaine Drugstore in Paris in 1974, and the murder of two French intelligence operatives in 1975) and they put pressure on the Sudanese Government to extradite him to France. This was refused, but after negotiations, Sanchez was effectively "sold" to France for "French military equipment, intelligence, training for Sudanese police, financial assistance to Sudan Airways, and a desalination plant for Port Sudan" (Burr and Collins (see note 10 above)). Al-Turabi allegedly visited Paris in July 1994, and Sanchez was abducted in August 1994. According to al-Turabi, the departure of Sanchez was justified because he "did not represent an ideology, he sold himself to various customers." Whilst Sanchez's behaviour in Sudan gave offence to many (he openly drank alcohol, and was a known womanizer) and he was not a Muslim, it is likely that the pragmatic benefits of gaining favor with the West and the French material and aid was of greater value at that time to the Sudanese authorities than his terrorist background. There is also some suggestion that potential French oil interests were a factor. These events may also be illustrative of what to many people has been thought of as a cynical willingness on al-Turabi's part to use events to develop his own interests, and to seek favour with the West. A further example of this may be seen in the apparent offers to "give" bin Laden to the U.S. (see note 33 below). There are other examples of militants being initially given refuge in Sudan, but subsequently leaving after pressure on the Sudanese government (for example, Rachid al Ghannouchi, a leader of Hizb al-Nahdah, the Tunisian Islamic Party).

31. http://cns.miis.edu/research/wmdme/sudan.htm. See also http://www.eretzyisroel. org/ jkatz/wmd.html - this details a number of assertions and allegations about the storage of Iraqi weapons (including chemical, biological and nuclear materials) most of which are unproveable and probably unfounded.

32. This attack was arguably the first directly initiated co-ordinated Al Qaeda attack. Reports implicating the Sudanese authorities seem to be misplaced.

33. On 3 March 1996 the Sudanese Minister of State for Defense, al-Fatih Urwah, reportedly held a secret meeting in Washington with Timothy M. Carney, the U.S. ambassador to Sudan, and David Shinn, Director of East African Affairs at the State Department (Richard Miniter, Losing Bin Laden: How Bill Clinton's Failures Unleashed Global Terror. (Washington, D.C.: Regnery Publishing, 2004). At this and at subsequent meetings, Sudan's willingness to arrest and transfer bin Laden to the U.S. was discussed. It is not clear if this initiative came from al-Turabi, or whether it was instigated by President Bashir without al-Turabi's consent or knowledge. The U.S. Government declined this offer, but it seems likely that these events provided the incentive to al-Turabi to initiate steps to facilitate bin Laden's departure from Sudan to Afghanistan, and on 18 May 1996 bin Laden left Sudan for Afghanistan. It seems likely that the principal motive behind this offer was not in fact to improve relations with the U.S., but rather with Saudi Arabia-Saudi officials were kept informed of discussions and bin Laden's eventual departure. Subsequently, the Sudanese Government made available to the U.S. authorities details of Al-Qaeda personnel who were in Sudan.

34. Burr and Collins (see note 10 above), 223.

35. D. M. Jones, M. L. R. Smith, and M. Weeding. "Looking for the Pattern: Al Qaeda in South East Asia: The Genealogy of a Terror Network." Studies in Conflict and Terrorism, 26; 2003, 443-457. 
36. In a visit to the ruined plant by the first author shortly after the attack, there was no obvious evidence of anything that appeared to be associated with chemical warfare. Indeed, there now seems to be a broad acceptance that this plant was not involved in the production of any chemical weapons. For a discussion of this see Karl Vick, "Sudan Plant's Tie With bin Laden Disputed," Washington Post Foreign Service, Thursday, 22 October, 1998, A29.

37. Taylor and Horgan (see note 1 above).

38. See for example K. Hundeide, "Becoming a Committed Insider," Culture and Psychology 9 (2003): 107-127.

39. Bin Laden does not have religious authority as a recognized member of the Ulama.

40. Coll (Steve Coll, "Young Osama: How He Learned Radiealism, and May Have Seen America," The New Yorker December 12, 2005) describes how radical Islamic teachers in his secondary school may have influenced bin Laden. The evidence presented is largely from interviews with fellow pupils at the Al Thagher Model School, which bin Laden is reported to have attended from 1968 until 1976. It is difficult to judge whether bin Laden's experiences were particularly different from other children, or if indeed (as Coll claims), he was introduced to and was influenced by teachers with backgrounds in the Ikwhan.

41. John L. Esposito and John O. Voll, Makers of Contemporary Islam. (Oxford: Oxford University Press, 2001, 120.

42. It should be noted that it is not always clear whether this is a reference to the Ulama as traditionally understood, or some other broader populist or different category.

43. M. Viorst, "Sudan's Islamic Experiment," Foreign Affairs, 74, no. 3, (May/June 1995): 53.

44. Not all these comments are necessarily accepted by observers as being truthful representations of al-Turabi's views; or at least there is a discrepancy between practice and rhetoric. Certainly the experience in Sudan of member of religious faiths other than Islam do not seem to be as positive as this quotation might suggest (see for example G. Lusk, Show of Tolerance, MEI, 5 February 1993, 14-15). On the other hand, there may indeed be a deliberate discrepancy between practice and rhetoric as much for local political reasons as anything else.

45. M. Viorst (see note 43 above).

46. Hamdi, (see note 6 above).

47. Hassan al-Turabi, "On the position of women in Islam and in Islamic Society," available online at http://www.islamfortoday.com/turabi01.htm. See also an interview with Wisal Sadiq Abdel Rahman al Mahdi, al-Turabi's wife, reported by Davis, (see note 18 above) 129-46.

48. Davis (see note 18 above) $27-8$.

49. The Training Manual can be found at http://www.usdoj.gov/ag/trainingmanual.htm

50. Ibid, Manual Part 1, 15.

51. See also http://english.aljazeera.net/NR/exeres/A78B0598-F7D6-48BF-90B3-CC044767C7BF.htm

52. Manual Part 1 (see note 49 above).

53. See multimedia.belointeractive.com/attack/military/1203book.html $107-127$

54. K. Hundeide, "Becoming a Committed Insider," Culture and Psychology 9 (2003):

55. See the discussion by Anatol Lieven: www.carnegieendowment.org/files/Remarks_ on $\% 20$ Chechnya $\% 20$ and $\% 20$ War $\% 20$ on $\% 20$ Terror.doc. From a different perspective, Johnson (James Turner Johnson, The War to Oust Saddam Hussein: Just War and the New Face of Conflict. (Lanham, MD: Rowman and Littlefield Publishers, 2005) makes the point that assumptions about contemporary politics that have no regard for the influence of religion "when these factors are indeed central to the motivations behind actions of people intent on harming us ... and when those people are not in fact organized into a state with its own "interests," then assumptions that allow no room for this are clearly inadequate," (page 5). Taylor and Horgan (2001) made similar points (Taylor, M. and Horgan, J. The Psychological and Behavioural bases of Islamic Fundamentalism. Terrorism and Political Violence, 2001, 13, $37-71)$.

56. Taylor and Horgan (see note 1 above). 